\title{
WHAT INFLUENCES BUSINESS TRAVELERS BEHAVIORAL INTENTIONS OF TRAVEL BOOKING: A STUDY OF THE BOTTLENECKS OF ONLINE TRAVEL PORTALS
}

\author{
Bivek DATTA* \\ Vishwakarma University Pune, Maharashtra, Department of Travel and Tourism, India, e-mail: bivek.datta@ vupune.ac.in
}

\begin{abstract}
Citation: Datta, B. (2021). WHAT INFLUENCES BUSINESS TRAVELERS BEHAVIORAL INTENTIONS OF TRAVEL BOOKING: A STUDY OF THE BOTTLENECKS OF ONLINE TRAVEL PORTALS. GeoJournal of Tourism and Geosites, 37(3), 929-933. https://doi.org/10.30892/gtg.37326-728
\end{abstract}

\begin{abstract}
This study aims to explore the bottlenecks of the Online Travel Portals while catering to business travelers. Data collection was done from Online Travel Portals and 379 foreign tourists using varied scales to determine their comprehensive perceived experience, technology adoption perception, the bottlenecks encountered and the ability to adapt while selecting online travel portals. Findings revealed that building trust is a major bottleneck for business travelers as they are skeptical of online transactions, cases of online thefts and internet security issues is another bottleneck. Safe and secure payment gateway is a big hurdle. Hotels booked through Online Travel Portals are sometimes not up to the mark and quality is a major bottleneck Online Travel Portals felt that expected tour components by the business travelers was the most problematic factor for them. Another problem was the unfavourable payment terms with the suppliers as well as non-availability of right accommodation demanded by the business travelers. Another bottleneck included not meeting the special needs of Business Travelers.
\end{abstract}

Key words: business travelers, booking, behavioral intention, bottlenecks, online travel portals

\section{INTRODUCTION}

Internet is a magical tool which has taken the whole world by storm but its birth year is a matter of debate. The scholarly literatures also throw little light on the same. Most of the literature focuses upon Arpanet developments with a popular belief that Internet was invented in Pentagon in 1969 (Sterling, 1992). The advent of this magical tool has opened the area for computer-mediated environment (CME) as it has augmented the movement patterns between various commercial set-ups (Hoffman et al., 1995). Consumer Behavior as a discipline came into limelight in the twentieth century with the prime objective of examining consumers action pertaining to receiving, using and finally consuming the goods and services. Various initial theories were studied to understand the complex consumer behavior such as the classical microeconomic theory but it was not enough to explain the consumers buying patterns. The consumer behavior evolved as a discipline in light of other schools of thought, which came from psychology, anthropology, sociology. The conceptual framework is taken from the Technology Acceptance Model (TAM) propounded by Davis in 1989. It explains the specific behavior of the consumer in an online environment. It explains the specific Behavior included from E-commerce. It explains in detail as to why the online consumers accept or reject the websites and the attitudes affecting their online behavior (Davis, 1989). By considering the Technology Acceptance Model an attempt has been made to understand the business traveler motivation and behavior pertaining to the purchase of travel products online. This new age business traveler is now adopting these Online Travel Portals. Digitization has changed the outlook of people and the distribution of tourism products is also impacted by this ecommerce revolution highlighted by many researchers (Kracht andWang 2010; Buhalis and Licata 2002; Bennett and Buhalis 2003). Douglas and Lubbe (2009) came across three areas pertaining to the degree of adoption of technology in business travel i.e. technology as a distribution tool for corporate travel booking, technological needs of corporate travelers across the corporate travel network, use of technology as a possible medium for corporate travel booking. Technological revolution presents opportunities for online travel portals through the internet (re-intermediation) and threats due to disintermediation, which includes direct bookings through suppliers. Some other previous studies throw light on the attitude of consumers towards online service providers, they beg to differ based on product, and service category (Law et.al., 2004). It is worth noting that the travel and tourism industry has embraced technology with open arms and are providing their valuable services in the information super highway. The Online Travel Agencies were the first to cash in the market opportunities by critically analyzing the value system that provides innovative ideas pertaining to new business opportunities (Mohammed et al., 2002).

\section{LITERATURE REVIEW}

\section{Consumer Perspective}

It does not matter whether a purchase is made through an offline mode or online mode. The consumers usually pass through five phases in consumer's decision-making process before procurement finally happens (Cetina et.al. 2012). These phases comprise of recognition of need, search for information, evaluating the alternatives, purchase decision and most importantly studying the post purchase behavior. Consumer Behavior as a discipline was in its nascent stage in the middle to late 1960s and after that, it has actually kept pace.

\footnotetext{
* Corresponding author
} 


\section{Need Recognition}

Understanding the consumer Behavior and their search pertaining to information is of paramount importance and will assist the decision makers to develop their websites and portals accordingly to satisfy the wants of the prospective consumers. Internet has developed as one of the significant instruments of consumer data (Zins, 2007) especially for the younger and educated travelers (Kim and Morrison, 2005). It is also witnessed that the mature and grey travelers prefer traditional and outmoded sources of information (Law and Ngai, 2005) and there are also travelers who use an intermix of internet and information from brick-and-mortar travel agencies for travel planning (Lee et al., 2007).

\section{Information Search}

It is also witnessed that consumers of different nationality, gender, age show dissimilar exploration patterns (Kim et al., 2007). People who have travelled earlier to a destination and know that place prefer to book it online but many still trust the travel agents Cheyne et al., 2006). In the era of internet quest instruments play a vital role in data search (Ho and Liu, 2005). Search engines such as google is viewed as a vital tool for information search (Law and Huang, 2006). Mobile technologies are a new find in the travel and tourism industry as they assist to collect information from any location and establish dynamic interaction with tourism service providers (Buhalis and Law, 2008). Tourism Marketers can use the GIS to keep an eye of the tourist movement pattern at the destination, understand the tourist Behavior at the destination, and devise strategies to create tourism experiences (Lau and McKercher, 2006).

\section{Evaluation of Alternatives}

Prospective travelers use the internet frequently to evaluate alternative travel opportunities and they use the internet to compare the travel products. The prospective travelers can detect and assess the tourism products conferring to their likings and necessities (Buhalis and O'Connor, 2005). It is also witnessed that prospective traveler's value information content and their data quest and behavioral patterns vary at different levels of travel (Choi et al., 2007). Online travel purchase motivation varies according to the complexity of the portal and the skill level of internet users (Beldona et al., 2005).

\section{Purchase Decision}

There is a great surge in understanding different consumers online Behavior as it could lead to an increase in successful completion of online transactions (Lexhagen, 2005). Early researches indicate that decision making initially focused on purchase decision making (Loudon and Britta, 1993). Modern studies on Marketing indicate that ideas of marketing were integrated in the studies of decision-making patterns pertaining to consumers (Engel et al., 1995). Purchase decision making process varies across people, choices and contexts (Xia and Sudarshan, 2002).

\section{Post -Purchase Behavior}

Travelers after visiting a particular destination have a longing to show their feelings and rate their know-how (Thevenot, 2007). They can express their experience in the form of blogs and through it they can communicate with the other travelers (Pudliner, 2007). The creation of a three-dimensional electronic tourism environment is likely to augment the vibrancy of digital ambience (Berger et al., 2007). Tourism Marketers should be vigilant pertaining to the digital environment and society and it will help them to know the customers view and the discussion of the brand online, which will help them to reinvent themselves (Dwivedi et al., 2007). It is imperative to understand the likings and varying needs of travelers by tourism businesses and it has been a vital area for research among the tourism academia, industry, consulting agencies. Tourist Behavior is one vital area because of the numerous factors associated with it. Various theories and models have been developed by researchers to understand the complex tourist behavior. The late twentieth century has seen the advent of Information and Communication Technology and the reason that can be attributed to it is globalization. Today's tourist is highly digitized and always connected. This generation of consumers is called C-generation also known as connected generation (Dimanche, 2010). This breed of traveler is not restricted to any age group. They are connected with each other through electronic devices. They were earlier named as e-consumers and the tourists connected through mobiles are known as m-tourists.

\section{Online Travel Portals}

Dhar and Wertenbroch (2000) opined that the Internet has emerged as a prime information source for the prospective customers and this trend is seen in many businesses. High levels of market transparency is witnessed which has helped the outlook of the consumers and information is readily available which is not observed via other distribution channels.

O'Connor and Frew (2002) were of the opinion that the Online Travel Portals offers manifold choices for a given search. It can serve manifold clients concurrently. Carroll and Siguaw (2003) opined that digitization has opened new vistas for travel related data, price assessment and readiness, which will support customers to book, travel products online. The advent of online booking is the most prominent discovery in the digital space and these digital platforms are likely to be used by individuals as well as corporate clients. O'Connor and Murphy (2004) were of the view that digitization has transformed many organizations. The advent of digitization has brought intense competition in the cyber space, and organizations are forced to adopt technology in order to survive in this highly competitive cyber space. Online travel portals have proved to be beneficial tools for individuals as it has assisted them in checking airfares and suitable flights and eventually book the ticket through the cyber space. Kim and Lee (2004) opined that the online travel portals and suppliers of online travel products provide common array of travel products. The common elements include the content of information, structure, security aspects, ease of use. Park et al., (2007) were of the opinion that the travel portals in the digital space are fiercely competing against each other and are revisiting their websites, as they have understood that only the efficient ones will survive in the end. 


\section{METHODOLOGY}

\section{Sampling and data collection}

a. The primary data was collected through a structured questionnaire consisting of both open ended and closed ended questions, which were asked to Business Travelers pertaining to their usage of Online Travel Portals for travel booking. Another questionnaire was prepared from the perspective of Online Travel Portals. Eight Online Travel Portals were targeted serving the needs and wants of business travelers. Business travelers filled the questionnaire at the departure lounge of IGI Airport, Delhi. The questions, which were asked in the questionnaire, were pertaining to the satisfaction of business travelers on important factors and overall satisfaction provided by Online Travel Portals. This was measured on a five-point Likert Scale. Apart from these parameters, some questions on demography were also included in the questionnaire. The business travelers were asked to respond on their perception pertaining to Online Travel Portals, information before considering it for booking their trips, convenience, adaptability, resolution of complaints. Apart from the primary data, the secondary data was also relied upon. This data was collected through a comprehensive analysis of the pertinent published data extracted from the Internet, reputed journals and scholarly books.

b. The data, which was collected through structured questionnaires from Online Travel Portals, was analyzed in a significant way to deduce useful and meaningful conclusions from it. The data collected from Business Travelers was carefully transmitted to the Statistical Package for Social Sciences for tabulation and analysis of data to deduce results. Kolmogorov-Smirnov test and chi-square test were used to study the bottlenecks of the online travel portals. The demographic data of the Business Travelers was analyzed and cross tabulated for understanding the trends in the data. The null hypothesis was rejected if the p value is less than 0.05 level of significance.

The Data Analysis was carried out through the following steps:

a. Primary Data was collected from independent business travelers pertaining to their requirements from Online Travel Portals, information source, their perception pertaining to the online travel portal, their satisfaction level i.e. pre and post usage of online travel portal.

b. The profile of the independent business travelers drawn on the questionnaire is on the basis of Gender, Marital Status, Age Group, Educational Level, occupation, Travelling companion, travel arrangements and duration of stay.

c. Descriptive and Analytical Statistics is employed

Table 1. Bottlenecks faced by Online Travel Portals (Source: Author)

\begin{tabular}{|c|c|c|c|c|c|c|c|c|c|}
\hline \multicolumn{10}{|c|}{ Bottlenecks faced by Online Travel Portals } \\
\hline & 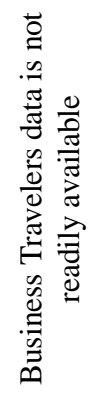 & 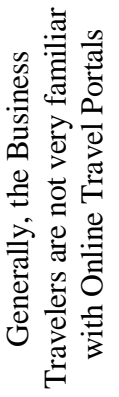 & 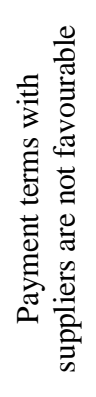 & 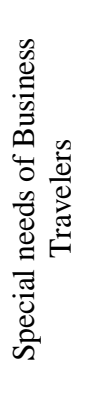 & 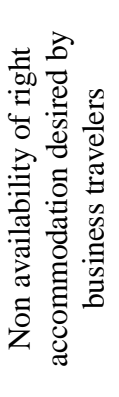 & 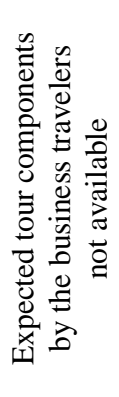 & 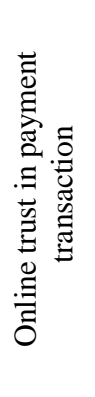 & 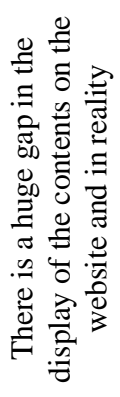 & 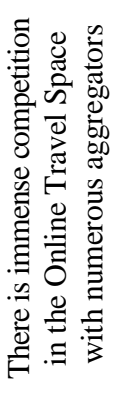 \\
\hline Mean & 1.3 & 1.4 & 2.2 & 2 & 2.2 & 2.4 & 1.4 & 1.3 & 1.3 \\
\hline Std. Deviation & 0.466 & 0.498 & 0.761 & 0.455 & 0.61 & 0.498 & 0.498 & 0.466 & 0.466 \\
\hline Skewness & 0.92 & 0.43 & -0.362 & 0 & -0.117 & 0.43 & 0.43 & 0.92 & 0.92 \\
\hline Std. Error of Skewness & 0.427 & 0.427 & 0.427 & 0.427 & 0.427 & 0.427 & 0.427 & 0.427 & 0.427 \\
\hline Kurtosis & -1.242 & -1.95 & -1.141 & 2.608 & -0.298 & -1.95 & -1.95 & -1.242 & -1.242 \\
\hline Std. Error of Kurtosis & 0.833 & 0.833 & 0.833 & 0.833 & 0.833 & 0.833 & 0.833 & 0.833 & 0.833 \\
\hline
\end{tabular}

Table 2. One-Sample Kolmogorov-Smirnov Test

\begin{tabular}{|l|l|l|l|l|l|l|l|l|l|}
\hline & & $\begin{array}{l}\text { Business } \\
\text { Travelers } \\
\text { data is } \\
\text { not } \\
\text { readily } \\
\text { available } \\
\text { Generally the } \\
\text { Tusiness } \\
\text { Travelers are } \\
\text { not very } \\
\text { familiar with } \\
\text { Online Travel } \\
\text { Portals }\end{array}$ & $\begin{array}{l}\text { Payment } \\
\text { terms with } \\
\text { suppliers } \\
\text { are not } \\
\text { favourable } \\
\text { Special } \\
\text { needs of } \\
\text { Business } \\
\text { Travelers }\end{array}$ & $\begin{array}{l}\text { Non } \\
\text { availability } \\
\text { of right } \\
\text { accommod } \\
\text { ation } \\
\text { desired by } \\
\text { business } \\
\text { travelers }\end{array}$ \\
\end{tabular}




\section{RESULTS, FINDINGS \&DATA INTERPRETATION}

Online Travel Portals were asked about the problems they faced in the selling the trips to the business travelers. The result of this survey helped to understand the bottlenecks in online travel portals. To utmost surprise it was felt that expected tour components by the business travelers was the most problematic factor (Table 1). The second big problem is the unfavourable payment terms with the suppliers as well as non-availability of right accommodation by the business travelers. The other bottlenecks include not meeting the special needs of Business Travelers. We can conclude pointing towards the individual problems, which is a bottleneck for the growth of online travel portals. It also indicates the lack of professional attitudes amongst the suppliers of services to the Online Travel Portals. Online Travel Portals must work in close cooperation with the suppliers of services so the business travelers can use their services pertaining to booking their trips.

Data is found to be normally distributed which we can witness from Table 2 after the application of KolmogorovSmirnov Test. The data is significant after the application of the chi-square test displayed in above Table3. It was further inferred that the responses of the Online Travel Portals are likewise disseminated in all the accounts barring the statement i.e., special needs of Business Travelers. The blockages in Online Travel Portals have also been understood through secondary sources through reports published by Online Travel Portals, research and consulting firms. The phenomenon of e-commerce has grown rapidly but it is still in the nascent stage. Another bottleneck is the trust building as business travelers are skeptical of online transactions as there are reported cases of online thefts and internet security issues. Convincing the travelers about a safe and secure payment gateway is a big issue. The reliability of offline partners is another issue. Hotels booked through Online Travel Portals are sometimes not up to the mark and reflects very badly on the image of the Online Travel Portals. Ensuring their quality is a major bottleneck. The payment terms with the service providers is the most problematic factor and is another major bottleneck for the Online Travel Portal.

Table 3. Chi-Square Test

\begin{tabular}{|c|c|c|c|c|c|c|c|c|c|}
\hline & $\begin{array}{c}\text { Business } \\
\text { Travelers } \\
\text { data is } \\
\text { not } \\
\text { readily } \\
\text { available }\end{array}$ & $\begin{array}{c}\text { Generally, the } \\
\text { Business } \\
\text { Travelers are } \\
\text { not very familiar } \\
\text { with Online } \\
\text { Travel Portals }\end{array}$ & $\begin{array}{c}\text { Payment } \\
\text { terms with } \\
\text { suppliers } \\
\text { are not } \\
\text { favourable }\end{array}$ & $\begin{array}{l}\text { Special } \\
\text { needs of } \\
\text { Business } \\
\text { Travelers }\end{array}$ & $\begin{array}{l}\text { Non-availability } \\
\text { of right } \\
\text { accommodation } \\
\text { desired by } \\
\text { business } \\
\text { travelers } \\
\end{array}$ & $\begin{array}{l}\text { Expected tour } \\
\text { components } \\
\text { by the } \\
\text { business } \\
\text { travelers not } \\
\text { available } \\
\end{array}$ & $\begin{array}{c}\text { Online } \\
\text { trust in } \\
\text { payment } \\
\text { transaction }\end{array}$ & $\begin{array}{c}\text { There is a } \\
\text { huge gap in } \\
\text { the display of } \\
\text { the contents on } \\
\text { the website } \\
\text { and in reality }\end{array}$ & $\begin{array}{l}\text { There is immense } \\
\text { competition in the } \\
\text { Online Travel } \\
\text { Space with } \\
\text { numerous } \\
\text { aggregators }\end{array}$ \\
\hline Chi-Square & $4.800^{\mathrm{a}}$ & $1.200^{\mathrm{a}}$ & $2.400^{\mathrm{b}}$ & $29.400^{b}$ & $11.400^{b}$ & $1.200^{\mathrm{a}}$ & $1.200^{\mathrm{a}}$ & $4.800^{\mathrm{a}}$ & $4.800^{\mathrm{a}}$ \\
\hline Df & 1 & 1 & 2 & 2 & 2 & 1 & 1 & 1 & 1 \\
\hline Asymp. Sig. & 0.028 & 0.273 & 0.301 & 0 & 0.003 & 0.273 & 0.273 & 0.028 & 0.028 \\
\hline
\end{tabular}

Chi-Square Results for the Bottlenecks of Online Travel Portals

a. 0 cells $(.0 \%)$ have expected frequencies less than 5 . The minimum expected cell frequency is 15.0 .

b. 0 cells $(.0 \%)$ have expected frequencies less than 5 . The minimum expected cell frequency is 10.0 .

\section{CONCLUSION, DISCUSSION \& FUTURE IMPLICATIONS}

Personal problems are the bottleneck for the growth of online travel portals. It also indicates the lack of professional attitudes amongst the suppliers of services to the Online Travel Portals. Online Travel Portals must work in close cooperation with the suppliers of services so that the business travelers for booking their trips can further utilize it. The following bottlenecks are identified in Online Travel Portals:

1. Non reliability of offline partners-Hotels booked through Online Travel Portals are sometimes not up to the mark and reflects badly on the image of the Online Travel Portals. Ensuring their quality is a major bottleneck;

2. Payment processing issues are also a major challenge faced by the Online Travel Agencies. This is a major bottleneck in the online travel portals as there are chances of online theft or server might not respond in time;

3. The payment terms with the service providers was the most problematic factor is a major bottleneck for the Online Travel Portal.

\section{LIMITATIONS AND SCOPE FOR FUTURE RESEARCH}

Business Travel has grown extensively in the last twenty years and in numerical terms its shared has dwindled between $14-16 \%$ of the total global inbound travel according to the purpose of travel (UNWTO Tourism Highlights). An investigation of the decision-making patterns of individual corporate travelers buying Business trips online is an important area of research and it is imperative to understand the online purchase behavior of this growing segment.

In numerical terms, the Business Travelers are a small segment in contrast to their counterpart i.e., leisure travelers but the segment is growing is growing slowly and steadily especially their revenue generating capabilities. Business Travel has come of age because of its low detrimental environmental impacts in comparison to their counterpart leisure mass travelers. As the world becomes a global village because of globalization and integrating economies. The communication technology is a medium, which has brought people close. The businesses are spreading their claws throughout the world. International corporate travel has become a requirement of business and spreading its claws, which pushes us into studying and researching their online purchase Behavior through Online Travel Portals.

1. Investigators can carry out in depth comparative analysis between the online Behavior of Leisure Travelers and Business Travelers through an intermix of both parametric and non-parametric tests.

2. More studies can be undertaken with a prolonged geographical area and prolonged sample size.

3. More studies can be carried out to study the online travel purchase Behavior of Outbound Leisure and Business Travelers. 


\section{REFERENCES}

Beldona, S., Morrison, A.M., \& O’Leary, J. (2005). Online shopping motivations and pleasure travel products: A correspondence analysis. Tourism Management, 26, 561-570. https://doi.org/10.1016/j.tourman.2004.03.008

Bennett, M., \& Buhalis, D., (2003). The Future for Internet Travel Distribution: the travel agent perspective, Insights. English Tourism Council, January 2003, pp. D.25-30

Berger, H., Dittenbach, M., Denk, M., Merkl, D., \& Pesenhofer, A. (2007). Getting Tourists Quicker to the Fun Part: Photographs, Tourist Types, Community Beings, and their Implications for a 3D e-Tourism Environment. Information Technology \& Tourism, 9(3), 211-226. https://doi.org/10.3727/109830507782167024

Buhalis, D., \& O'Connor, P. (2005). Information Communication Technology - Revolutionising Tourism. Tourism Recreation Research, 30(3), 7-16. https://doi.org/10.1080/02508281.2005.11081482

Buhalis, D., \& Law, R. (2008). Progress in information technology and tourism management: 20 years on and 10 years after the internet: The state of eTourism research. Tourism Management, 29 (4), 609-623. https://doi.org/10.1016/j.tourman.2008.01.005

Buhalis, D., \& Licata, C. (2002). The future of eTourism intermediaries. Tourism Management, 23(3), 207-220. https://doi.org/10.1016/S0261-5177(01)00085-1

Carroll, B., \& Siguaw, J. (2003). The evolution of electronic distribution: Effects of hotels and intermediaries. Cornell Hotel and Restaurant Administration Quarterly, 44(4), 38-50.

Cheyne, J., Downes M., \& Legg, S. (2006). Travel agent vs Internet: What Influences Consumer Choices? Journal of Vacation Marketing, 12(1), 41-57. https://doi.org/10.1177/1356766706059307

Choi, S., Lehto, X.Y., \& O'Leary J.T. (2007). What does the consumer want from the DMO Website? A study of the US and Canadian tourist's perspectives. International Journal of Tourism Research, 9(2), 59-72. https://doi.org/10.1002/jtr.594

Davis, F.D. (1989). Perceived usefulness, perceived ease of use, and user acceptance of information technology. MIS Quarterly, 13(3), 319-339. https://doi.org/10.2307/249008

Dhar, R., \& Wertenbroch, K. (2000). Consumer Choice between Hedonic and Utilitarian Goods. Journal of Marketing Research, $37(1), 60$ - 71.

Dimanche, F., \& Andrades L. (2010). Tourism in Russia: A Management Handbook

Douglas, A., \& Lubbe, B. (2009).Violation of the Corporate Travel Policy: an Exploration of Underlying Value/related Factors. Journal of Business Ethics, 84(1), 97-111. https://doi.org/10.1007/s10551-008-9676-5

Dwivedi, M., Shibu, T.P., \& Venkatesh, U. (2007). Social Software Practices on the Internet. International Journal of Contemporary Hospitality Management, 19(5), 415-416. https://doi.org/10.1108/09596110710757570

Engel, J., Blackwell, R.D., \& Miniard, P. (1995). Consumer Behavior, (8 Ed.) Forth Worth, TX: Dryden.

Ho, C., \& Liu, Y. (2005). An exploratory investigation of Web based tourist information search Behavior. Asia Pacific Journal of Tourism Research.10 (4), 351-60. https://doi.org/10.1080/10941660500363645

Hoffman, D.L., Novak, T.P., \& Chatterjee, P. (1995). Commercial Scenarios for the Web: Opportunities and Challenges. Journal of Computer Mediated Communication. 1(3), 3,0-0. https://doi.org/10.1111/j.1083-6101.1995.tb00165.x

Kim, D.Y., Lehto, X.Y., \& Morrison, A.M. (2007). Gender Differences in Online Travel Information Search: Implications for Marketing Communications on the Internet. Tourism Management, 28(2), 423-433. https://doi.org/10.1016/j.tourman.2006.04.001

Kim, J., \& Larose, R. (2006). Interactive E-Commerce: Promoting Consumer Efficiency or Impulsivity? Journal of Computer-Mediated Communication. https://doi.org/10.1111/j.1083-6101.2004.tb00234.x

Kim, S., \& Morrison, A. (2005). Change of Images of South Korea among Foreign Tourists after the 2002 FIFA World Cup. Tourism Management, 26 (2), 233-47. https://doi.org/10.1016/j.tourman.2003.11.003

Cetina, I., Munthiu, M.C., \& Radulescu, V. (2012). Psychological and social factors that influence online consumer Behavior. Procedia Social and Behavioral Sciences, 62(2012), 184-188, Bucharest. https://doi.org/10.1016/j.sbspro.2012.09.029

Kracht, J., \& Wang, Y. (2010). Examining the tourism distribution channel: Evolution and Transformation. International Journal of Contemporary Hospitality Management, 22 (5), 736 - 757. http://dx.doi.org/10.1108/09596111011053837

Lau, G., \& McKercher, B. (2006). Understanding tourist movement patterns in a destination: A GIS Approach. Tourism and Hospitality Research.7 (1), 39-49. https://doi.org/10.1057/palgrave.thr.6050027

Law, R., \& Ngai, C. (2005). Usability of travel websites: A case study of the perceptions of Hong Kong travelers. Journal of Hospitality \& Leisure Marketing, 13(2), 19-31. http://dx.doi.org/10.1300/J150v13n02_03

Law, R., Leung, K., \& Wong, J. (2004). The impact of the Internet on travel agencies. International Journal of Contemporary Hospitality Management, 16(2), 100-107. http://dx.doi.org/10.1108/09596110410519982

Law, R., \& Huang, T. (2006). How do travelers find their travel and hotel websites? Asia Pacific Journal of Tourism Research, 11(3), 239-246. https://doi.org/10.1080/10941660600753273

Lee, J., Soutar, G., \& Daly, T. (2007). Tourists' Search for Different Types of Information: A Cross-National Study. Information Technology \& Tourism, 9(3).165-176. https://doi.org/10.3727/109830507782167006

Lexhagen, M. (2005). The Importance of Value-Added Services to Support the Customer Search and Purchase Process on Travel Websites. Information Technology \& Tourism, 7(2), 119- 135. https://doi.org/10.3727/10.3727/1098305054517336

Loudon, D.L., \& Britta, A.J.D. (1993). Consumer Behavior: concepts and applications, (4 ed.) McGraw Hill.

Mohammed, R.A., Fisher, R.J., Jaworski, B.J., \& Cahill, A.M. (2002). Internet marketing: Building advantage in a networked economy. New York: McGraw-Hill//rwin

O’Connor, P., \& Murphy, J. (2004). Research on information technology in the hospitality industry. International Journal of Hospitality Management. 23(5), 473-484

O'Connor, P., \& Frew, A. (2002). The future of hotel electronic distribution: expert and industry perspectives. Cornell Hotel and Restaurant Administration Quarterly.43 (3), 33-45.

Park, Y, Gretzel, U., \& Sirakaya-Turk, E. (2007). Measuring web site quality for online travel agencies. Journal of Travel and Tourism Marketing, 23(1), 15-30. https://doi.org/10.1300/J073v23n01_02

Pudliner, B.A. (2007). Alternative Literature and Tourist Experience: Travel and Tourist Weblogs. Journal of Tourism \& Cultural Change, 5 (1), 46-59. https://doi.org/10.2167/jtcc051.0

Sterling, B. (1992).The hacker crackdown:Law and Disorder on the Electronic Frontier. London: Penguin.

Thevenot, G. (2007). Blogging as a Social Media. Tourism and Hospitality Research, 7(3/4), $287-289$. https://doi.org/10.1057/palgrave.thr.6050062

Xia, L., \& Sudharshan, D. (2002). Effects of interruptions on consumer online decision processes. Journal of Consumer Psychology, 12(3), 265-280. https://doi.org/10.1207/S15327663JCP1203_08

Zins, C. (2007). Conceptual approaches for defining data, information, and knowledge. Journal of American Society of Information Science, 58(4), 479-493. https://doi.org/10.1002/asi.20508 